\title{
EFFECT OF LOCALLY SOURCED NIGERIAN GYPSUM ON THE STRENGTH AND MICROSTRUCTURE OF PORTLAND CEMENT MORTAR
}

\author{
A. D. Muhammad ${ }^{1}$, Y. D. Amartey ${ }^{2}$, J. M. Kaura ${ }^{3,}{ }^{*}$, T. S. Ijimdiya ${ }^{4}$ and A. Lawan ${ }^{5}$ \\ $\mathbf{1 , 2 , 3 , 4 , 5}$, Department of Civil Engineering, Ahmadu Bello University, ZARIA, KadunA STATE, NIGERIA \\ Email addresses:1 amdgari@gmail.com, ${ }^{2}$ dadaamartey@yahoo.com, ${ }^{3}$ jdanbala@yahoo.co.uk, \\ ${ }^{4}$ tsijimdiya@abu.edu.ng, 5 bnlawan@yahoo.co.uk
}

\begin{abstract}
The objective of this study was to investigate the suitability of Nigerian, sourced Gypsum for the manufacture of Portland cement. Gypsum samples were obtained from eighteen deposits across Nigeria. These were classified into five purity groups based on their calcium sulphate content. Foreign Gypsum, imported from Morocco, was used as control. Six cement samples where produced for each of the five Gypsum purity groups by grounding and blending cement clinker with 3\%, 4\%, 5\%, 6\% and 7\% Gypsum content. The group 1 cement mix (having not more than 65\% calcium sulphate content) has displayed flash set and could not be moulded and therefore not used for further analysis. Cement mortar prisms were produced for the groups 2, 3, 4 and 5 cement mixes, and subjected to flexural and compressive strength tests at 7, 14, 21 and 28 day curing periods. The cement mortar prisms were also subjected microstructure analysis at 7 and 28 days curing period. The spongy, gel and whitish colouration observed from the microstructure of the specimens indicated silicates enriched regions which have proven the strength increase from 7 to 28 day curing period. The optimum gypsum content of 5.5\% was recommended. The results show that all but the class one gypsum with less than $65 \%$ purity content are suitable for cement manufacture.
\end{abstract}

Keywords: Gypsum, clinker, mortar, microstructure, compressive strength, flexural strength

\section{INTRODUCTION}

Systematic studies of the influence of gypsum content on portland cement have shown that there is an optimum content which produces the highest strength and the lowest drying shrinkage [1]. In the construction industry, strength is a primary criterion in selecting a concrete for a particular application. The hydration and hardening of cement is a process that occurs over a long period. With the increase of the hydrating degree of various clinker minerals in cement particles, gels will grow and capillary porosities will decrease, which enables the strength to rise with the increase in age. It was proved that cement develops rapidly within 28 days and slowly thereafter [2]. Concrete has a heterogeneous microstructure, which consists of three components, namely: cement paste, pore structure, and interfacial transition zone between the cement paste and aggregates with the distribution of each affecting the properties and performance of the material [3]. Improving these three components leads to enhanced mechanical strength and durability of concrete [4]. Data on crystal size, shape and distribution in the microstructure of mortar provides information on the strength development [5]. Microstructure is obtained using Scanning Electron Microscopy (SEM). It is one of the most popular imaging techniques. It has been extensively used for material characterization, especially in combination with energy dispersive X-ray microanalysis [3]. This paper presents the results of the evaluation of the influence of varying localy sourced Nigerian gypsum

* Corresponding author: +234-802 - 358- 3817 
addition on the strength and microstructure of cement. This was achieved through flexural and compressive strength tests as well as results interpretation in conjunction with micrographs obtained from scanning electron microscopy test. The primary objective was the determination of the optimum gypsum content required for the production of good quality cement in terms of strength and durability.

\subsection{Background of the Study}

Two of the main parameters that determines cement quality are the setting time and the compressive strength. Gypsum acts in parallel as a regulator of both parameters. Thus, its impact on cement quality of cement is dual and crucial. Gypsum addition retards the fast-exothermic reaction of tricalcium aluminate $\left(3 \mathrm{CaO} \cdot \mathrm{Al}_{2} \mathrm{O}_{3} / \mathrm{C}_{3} \mathrm{~A}\right)$ by forming ettringite. Generally, $\mathrm{C}_{3} \mathrm{~A}$ reacts with the calcium sulphate phases basanite- $\mathrm{CaSO}_{4} .0 .5 \mathrm{H}_{2} \mathrm{O}$, gypsum $\mathrm{CaSO}_{4} \cdot 2 \mathrm{H}_{2} \mathrm{O}$ and anhydrite- $\mathrm{CaSO}_{4}$. [6].

However excessive amount of gypsum leads to abnormal and detrimental expansion and consequent disruption of the set cement paste. Optimum gypsum content leads to a desirable rate of early reaction and prevents local high concentration of products of hydration. Hence maximum limit needs to be clearly defined [7].

\subsection{Literature Review}

Mortars are porous materials with a heterogeneous and complex structure, making difficult their characterization. Today, the technological development of cement-based materials is intimately connected to the study of the microstructure and porosity of those materials $[8,9]$.

The main source of strength in concrete is the adhesion between the solid products of hydrated cement paste. This adhesion can be attributed to the van-der-waals forces of attraction with degree of adhesion that depend on the nature of the solid surfaces involved. Some of hydrated products, such as calcium silicate hydrates (C-S-H) crystals, calcium sulphoaluminate hydrates, and hexagonal calcium aluminate hydrates, possess vast surface areas and adhesive capability. Therefore, they tend to adhere strongly to each other and at the same time to solids with low surface areas such as lime, anhydrous cement particles, and aggregate particles [10].

SEM image analysis has become an important tool for microscopic studies of bio-aggregates based materials $[9,11]$. Walker and Pavia [11] studied the microstructure and pore size of hemp lime concrete using Field Emission SEM. The results showed that the morphology of hemp interface changed over time, from predominantly needle-shape at early ages to sponge and gel types at later ages. In consequence, the size of pores in hydrated cement paste is reduced and strength is increased.

\subsection{Role of Gypsum in Cement Production}

When cement is mixed with water, it becomes hard over a period of time. This is called setting of cement. Gypsum is often added to portland cement to prevent early hardening or "flash setting", allowing a longer working time. Gypsum slows down the setting times so that cement is adequately hardened.

The retardation mechanism of gypsum is: when cement is hydrated, gypsum reacts with tri calcium aluminate $\left(\mathrm{C}_{3} \mathrm{~A}\right)$ quickly to generate calcium sulphoaluminate hydrate which deposits and forms a protection film on the cement particles to hinder the hydration of $\mathrm{C}_{3} \mathrm{~A}$ and delay the setting time of cement. If the content of gypsum is too little, the retardation effect will not be significant. Too much gypsum will accelerate the setting of cement because gypsum can generate a clotting agent itself. The appropriate amount of gypsum depends on the content of $\mathrm{C}_{3} \mathrm{~A}$ in the cement and that of $\mathrm{SO}_{3}$ in gypsum, and it is also related to the fineness of cement and the content of $\mathrm{SO}_{3}$ in clinker. If the content of gypsum exceeds the limit, it will lower the strength of cement and it can even lead to poor dimensional stability, which will cause expansion and destruction of cement paste $[4,15]$. The amount of gypsum added to cement clinker is limited by European Standard BS EN 197-1: 2000 [12].

\section{MATERIALS AND METHODS}

\subsection{Materials}

\subsubsection{Gypsum}

The local Gypsum samples were sourced from Goronyo, Shagari, Wurno, Gada local government areas of the North West geo-political zone, Fika, Gulani, Fune, Yola South, Bajoga, Nafada, Alkaleri, Karin-lamido, Kwaya-kusar, Bayo of the North East zone, Egbado South of the South West Zone, Etsako West and Obubra of the South south zone and Ishielu local government area of the South East Zone. The samples were screened and classified into the three groups (group 2, 3 and 4) presented in 
Table 1. One imported Gypsum sample originated from Morocco, was also sourced from the Obajana plant of Dangote cement industries and coded as group 5.

\subsubsection{Sand}

The Sand used for the tests was natural siliceous sand consisting of rounded particles as prescribed in the BS EN 196-1, 2000 [14], obtained from the quality control laboratory of the cement company of northern Nigeria, Sokoto.

\subsubsection{Water}

Ordinary tap water which is fit for drinking has been used in preparing all mortar mixes and curing.

\subsection{Methods}

\subsubsection{The Gypsum Purity}

The purity of gypsum was obtained by the estimate of its composition of $\mathrm{CaO}$ and $\mathrm{SO}_{3}$ content. The composition of the $\mathrm{CaO}+\mathrm{SO}_{3}$ for each of the nineteen considered gypsum are presented in Table 1.0. The elemental composition was established using X-Ray Fluorescence Spectrometry (XRF).The eighteen locally sourced Nigerian gypsum were classified into three grades based on the calcium sulphate $\left(\mathrm{CaSO}_{4} .2 \mathrm{H}_{2} \mathrm{O}\right)$ contents, while the fourth grade was for the imported gypsum, selected to enable us have a comparative study with the locally sourced product. The frequency distribution table was formed based on the gypsum purity, presented in Table 2.0

\subsubsection{Production of the cement}

In this study, thirty (30) cement samples were produced by blending the cement clinker with the locally sourced gypsum at various percentages at the quality control laboratory of the Cement Company of Northern Nigeria (CCNN) Sokoto using ball mixer. The mix composition for the cement clinker/gypsum blend is presented in Table 3.0.

All the cement mixes were subjected to specific gravity, consistency and setting time tests. The values obtained for the group 1 cement mixes with respect to the specific gravity, fineness, consistency, initial setting time, final setting time and soundness ranged between $(3.17-\mathrm{m} 3.34),\left(4,057 \mathrm{~cm}^{2} / \mathrm{g}-\right.$ $\left.4,275 \mathrm{~cm}^{2} / \mathrm{g}\right),(50 \%-61 \%),(4 \mathrm{~min}-8 \mathrm{~min} 0,(6 \mathrm{~min}-$ $15 \mathrm{~min})$ and $(9 \mathrm{~mm}-13 \mathrm{~mm})$ respectively. It is therefore clear from this result that the consistency, initial setting time, final setting time and soundness could not meet the minimum requirement provided by BS EN 197-1 [12]. Likewise due to very small quantity of $\mathrm{SO}_{3}$ in the group $1 \mathrm{mix}$, resulting from the low quality gypsum (lowest gypsum purity), flash setting was obtained upon mixing with water. As such, the cement group 1 mix could not be moulded. Therefore, only cement groups 2, 3, 4 and 5 mixes are considered for the production of the test specimens.

Therefore, three Hundred and Fifteen (315) prismatic cement mortar test specimens, $400 \mathrm{~mm} \times$ $400 \mathrm{~mm} \times 16 \mathrm{~mm}$ in size were produced. These specimens were cast from a batch of mortar containing one part by mass of cement, 3 parts by mass of CEN standard sand and one-half part of water (water/cement ratio 0.50). The mortar was prepared by mechanical mixing and was compacted in a mould using a jolting apparatus. The specimens were then stored in the mould in a moist atmosphere for 24 hours and, after demoulding, specimens were kept under water until the commencement of the strength testing. At the ages of 7 and 28 days. Plate I show the moulding process of the specimen. The specimens were then subjected to flexural and compressive strength tests in accordance with BS EN 196 part 1- 2000 [14], and NIS 446, 2003 [16] specification.

Three-point bending test was used for the flexural strength tests. The testing machine induce flexure on specimen by means of two steel supporting rollers approximately $100 \mathrm{~mm}$ apart and the third steel loading roller of the same diameter placed centrally above between the other two. The reading is taken when the specimen breaks into two halves. For the determination of compressive strength, test halves obtained from flexural tests were centered suitably to the machine platens and loaded until the specimen fractures. Also, microscopic analysis was performed on the cement mortar with results obtained using Scanning Electron Microscope (SEM).

\section{RESULTS AND DISCUSSION}

\subsection{Flexural Strength of the Cement Mortar}

Figures 1, 2, 3 and 4 show the variation of the flexural strength of the cement mortar with gypsum content for cement mix group 2, 3, 4 and 5 respectively. In Figure 1, the flexural strength of the mortar with $3 \%$ gypsum content increased from $4.5 \mathrm{~N} / \mathrm{mm}^{2}$ at 7 days curing period to $4.9 \mathrm{~N} / \mathrm{mm}^{2}$, $5.3 \mathrm{~N} / \mathrm{mm}^{2}$ and $5.6 \mathrm{~N} / \mathrm{mm}^{2}$ respectively at 14 days, 21 days and 28 days curing period. 
Table 1: Composition of Gypsum Purity (Gypsum

\begin{tabular}{|c|c|c|}
\hline \multicolumn{3}{|c|}{ Purity) } \\
\hline $\mathrm{S} / \mathrm{N}$ & Source of the Gypsum & $\begin{array}{l}\text { Percentage Composition } \\
\left(\mathrm{CaO}+\mathrm{SO}_{3}\right)\end{array}$ \\
\hline 1 & $\begin{array}{l}\text { Karin-Lamido, Taraba } \\
\text { State }\end{array}$ & 19.36 \\
\hline 2 & Goronyo, Sokoto State & 67.96 \\
\hline 3 & $\begin{array}{l}\text { Kwaya-kusur, Borno } \\
\text { State }\end{array}$ & 71.15 \\
\hline 4 & Bayo, Borno State & 71.35 \\
\hline 5 & Wurnu, Sokoto State & 71.48 \\
\hline 6 & Alkaleri, Bauchi State & 72.41 \\
\hline 7 & $\begin{array}{l}\text { Yola South, Adamawa } \\
\text { State }\end{array}$ & 73.10 \\
\hline 8 & Gulani, Yobe State & 76.17 \\
\hline 9 & $\begin{array}{l}\text { Obubra, Cross River } \\
\text { State }\end{array}$ & 76.77 \\
\hline 10 & Bajoga, Gombe State & 76.77 \\
\hline 11 & Fika, Yobe State & 77.12 \\
\hline 12 & $\begin{array}{l}\text { Etsako West, Edo } \\
\text { State }\end{array}$ & 77.19 \\
\hline 13 & Ishielu, Ebonyi State & 77.19 \\
\hline 14 & Shagari, Sokoto State & 77.22 \\
\hline 15 & Nafada, Gombe State & 77.30 \\
\hline 16 & Fune, Yobe State & 77.51 \\
\hline 17 & $\begin{array}{l}\text { Egbado South, Ogun } \\
\text { State }\end{array}$ & 77.72 \\
\hline 18 & Gada, Sokoto State & 78.02 \\
\hline 19 & $\begin{array}{l}\text { Imported Sample from } \\
\text { Morocco }\end{array}$ & 79.10 \\
\hline
\end{tabular}

Table 2: Classification of the Gypsum Quality

\begin{tabular}{llll}
\hline \multirow{2}{*}{$\begin{array}{l}\text { Group Identification } \\
\text { Number }\end{array}$} & Location & \multicolumn{2}{c}{ Calcium Sulphate } \\
\cline { 3 - 4 } & & \multicolumn{2}{c}{ Content (\%) } \\
\hline 1 & Lower limit & $\begin{array}{l}\text { Upper } \\
\text { limit }\end{array}$ \\
\hline 2 & Nigeria & Less than & --- \\
3 & Nigeria & 65.0 & 70.01 \\
4 & Nigeria & 70.01 & 75.00 \\
5 & Nigeria & 75.01 & 80.00 \\
\hline
\end{tabular}

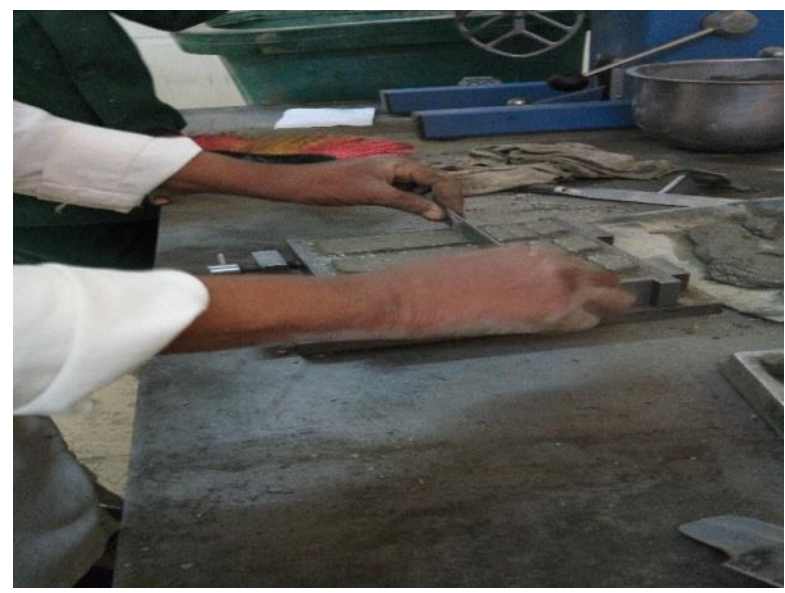

Plate I: Moulding of the Mortar Prisms

Table 3: Cement Mix Composition used in the study

\begin{tabular}{llllll}
\hline Serial Number & Mix Group No. & Cement ID & Gypsum Quality (Purity) Group & Percentage Clinker & Percentage Gypsum \\
\hline Cement & 1 & Cem 1A & $65 \%$ or less & 98 & 2 \\
Group & 1 & Cem 1B & pure & 97 & 3 \\
1 & 1 & Cem 1C & & 96 & 4 \\
& 1 & Cem 1D & 95 & 5 \\
& 1 & Cem 1E & 94 & 6 \\
& 1 & Cem 1F & 93 & 7 \\
Cement & 2 & Cem 2A & & 98 & 2 \\
Group & 2 & Cem 2B & More than 65\% & 97 & 3 \\
2 & 2 & Cem 2C & 96 & 4 \\
& 2 & Cem 2D & Less than 70\% & 95 & 5 \\
& 2 & Cem 2E & pure & 94 & 6 \\
Cement & 2 & Cem 2F & & 93 & 7 \\
Group & 3 & Cem 3A & & 98 & 2 \\
3 & 3 & Cem 3B & More than 70\% & 97 & 3 \\
& 3 & Cem 3C & Less than 75\% & 96 & 4 \\
& 3 & Cem 3D & pure & 95 & 5 \\
& 3 & Cem 3E & & 94 & 6 \\
Cement & 3 & Cem 3F & 93 & 7 \\
Group & 4 & Cem 4A & 98 & 2 \\
4 & 4 & Cem 4B & More than 75\% & 97 & 3 \\
& 4 & Cem 4C & 96 & 4 \\
& 4 & Cem 4D & Less than 80\% & 95 & 5
\end{tabular}




\begin{tabular}{llllll}
\hline Serial Number & Mix Group No. & Cement ID & Gypsum Quality (Purity) Group & Percentage Clinker & Percentage Gypsum \\
\hline \multirow{2}{*}{ Cement } & 4 & Cem 4F & & 93 & 7 \\
Group & 5 & Cem 5A & & 98 & 2 \\
5 & 5 & Cem 5B & Foreign based & 97 & 3 \\
& 5 & Cem 5C & More than 75\% & 96 & 4 \\
& 5 & Cem 5D & Less than 80\% & 95 & 5 \\
& 5 & Cem 5E & pure & 94 & 6 \\
& 5 & Cem 5F & & 93 & 7
\end{tabular}

As the gypsum content increased continuously to 7, the maximum flexural strengths occurs at $6 \%$ for 7 and 14 days curing period and at $5 \%$ for 21 and 28 days curing period. It is clear that the optimum 28 days flexural strength for the cement mix 2 is $6 \mathrm{~N} / \mathrm{mm}^{2}$. Therefore for cement mix $2,5 \%$ is the optimum Gypsum content.

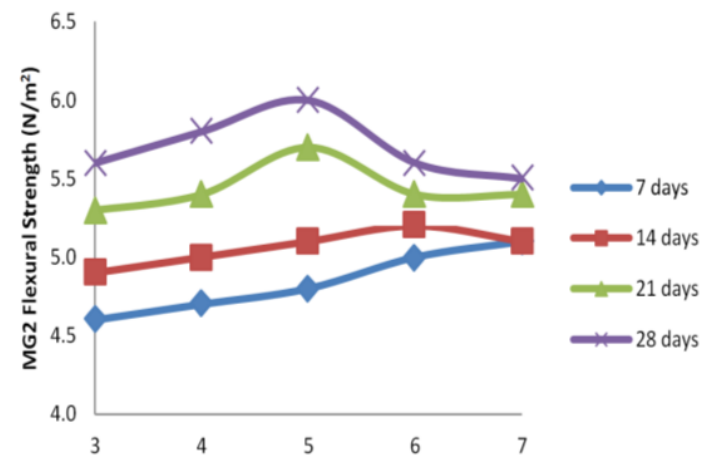

Figure 1: Variation of flexural strength with Gypsum content for cement mix groups 2 at 7, 14, 21 and 28 days curing period

Also in Figure 2, the flexural strength of the cement mortar for cement mix group 3 increases with increasing gypsum content at all curing ages up to the optimum gypsum content of $6 \%$. The corresponding optimal flexural strengths are 6.2 $\mathrm{N} / \mathrm{mm}^{2}, 6.4 \mathrm{~N} / \mathrm{mm}^{2}, 6.4 \mathrm{~N} / \mathrm{mm}^{2}, 6.8 \mathrm{~N} / \mathrm{mm}^{2}$ and 7.0 $\mathrm{N} / \mathrm{mm}^{2}$ at 7 days, 14 days, 21 days and 28 days curing period respectively. This implied that higher ultimate flexural strength of cement mortar is achieved for cement mix 3 than cement mix group 2.

Similar trends in observed in Figure 3 for cement mix group 4. However, the optimum gypsum content is $5 \%$ and the corresponding optimal flexural strengths at $7,14,21$ and 28 days are respectively $5.9 \mathrm{~N} / \mathrm{mm}^{2}$, $6.1 \mathrm{~N} / \mathrm{mm}^{2}, 6.4 \mathrm{~N} / \mathrm{mm}^{2}$ and $6.9 \mathrm{~N} / \mathrm{mm}^{2}$. It is clear from the results presented in Figure 2 and 3 that achieved flexural strength capacities for cement mix group 2 and mix group 3 are approximately the same with cement mix group 3 having low optimal gypsum content.
Figure 4 displayed the relationship between flexural strength of the cement mortar for cement mix group 5 at various curing ages. The imported gypsum is used for the cement mix group 4. The optimum gypsum content is $6 \%$ with corresponding optimal flexural strength of $6.3 \mathrm{~N} / \mathrm{mm}^{2}, 6.5 \mathrm{~N} / \mathrm{mm}^{2}, 7.0$ $\mathrm{N} / \mathrm{mm}^{2}$ and $7.2 \mathrm{~N} / \mathrm{mm}^{2}$ respectively. The results indicate that the cement mix group 5 produced mortar with the highest flexural strength

\subsection{Compressive Strength of the Cement Mortar}

Figure 5, 6, 7 and 8 shows the variation of the compressive strength of the cement mortar with gypsum content for cement mix groups 2, 3, 4 and 5 respectively. As indicated in Figure 5 , the compressive strengths of the mortar prisms at $3 \%$ gypsum content are $35 \mathrm{~N} / \mathrm{mm}^{2}, 38 \mathrm{~N} / \mathrm{mm}^{2}, 38 \mathrm{~N} / \mathrm{mm}^{2}$ and $42 \mathrm{~N} / \mathrm{mm}^{2}$ respectively at $7,14,21$ and 28 days curing period. The compressive strength increases as the gypsum content increases up to $5 \%$ gypsum content, after which the compressive strength started decreasing for the considered curing periods of 7, 14, 21 and 28 days. Therefore, the optimum compressive strengths corresponding to the respective curing periods for cement mix group 2 are $32 \mathrm{~N} / \mathrm{mm}^{2}, 34 \mathrm{~N} / \mathrm{mm}^{2}, 36 \mathrm{~N} / \mathrm{mm}^{2}$ and $38 \mathrm{~N} / \mathrm{mm}^{2}$.

In Figure 6, the effect of gypsum content on the compressive strength of the cement mortar for cement mix group 3 is presented. The trend is similar to what was observed in Figure 5. However, the optimum gypsum content in this case is $6 \%$ as against $5 \%$ for cement mix group 2 . The corresponding optimal compressive strengths are 40 $\mathrm{N} / \mathrm{mm}^{2}, 42 \mathrm{~N} / \mathrm{mm}^{2}, 45 \mathrm{~N} / \mathrm{mm}^{2}$ and $47 \mathrm{~N} / \mathrm{mm}^{2}$ respectively at 7, 14, 21 and 28 days curing periods. The results shown superior performance of the cement mix group 3 over cement mix group 2 .

The effect of the gypsum content on the compressive strength of the mortar prism for cement mix group 4 is presented in Figure 7. It is clear from the plot that the optimum compressive strength at 7 and 14 days curing periods were achieved at $5 \%$ gypsum content 
with corresponding compressive strengths of 40 $\mathrm{N} / \mathrm{mm}^{2}$ and $44 \mathrm{~N} / \mathrm{mm}^{2}$.

However, the optimum gypsum content increased from $5 \%$ to $6 \%$ at 21 and 28 day curing periods with corresponding compressive strengths of $46 \mathrm{~N} / \mathrm{mm}^{2}$ and $48 \mathrm{~N} / \mathrm{mm}^{2}$. This result indicates superior performance of cement mix group 4 over mix groups 2 and 3.

In Figure 8, the relationship between compressive strength of the mortar prism for cement mix group 5 is presented. As observed in the previous plots, the compressive strengths of the mortar prisms increased with increasing gypsum content. At 7 and 14 day curing period, the maximum compressive strengths of $48 \mathrm{~N} / \mathrm{mm}^{2}$ and $50 \mathrm{~N} / \mathrm{mm}^{2}$ are achieved at $6 \%$ gypsum content. However, the optimum gypsum content corresponding to 21 and 28 day curing period is $5 \%$ with corresponding compressive strength of $51 \mathrm{~N} / \mathrm{mm}^{2}$ and $54 \mathrm{~N} / \mathrm{mm}^{2}$.

As presented in Table 2, the quality of gypsum in the cement mix group 5 is the most superior and it is the imported gypsum which is taken as the control in this research. The results presented in Figures 1 to 8 , shows that the values of the flexural and compressive strengths for the cement mix group 5 are higher than those obtained for the cement groups 2, 3 and 4 . The observed increase in flexural and compressive strengths with increasing gypsum content could be as a result of increase in Sulphur trioxide $\left(\mathrm{SO}_{3}\right)$ which aids the formation of ettringite at threshold levels and accelerates the hardening process of the mortar and thus hastens strength gain at early ages.

This assertion had been substantiated with the findings of Bhanumathidas and Kalidas [6] and Abdelrahman and Mohamad [11]. Gypsum ground with clinker would dissolve immediately in water and the sulphate ions will react with $C_{3} A$ to form insoluble calcium sulphoaluminate (ettringites) which deposits on the surface of the $\mathrm{C}_{3} \mathrm{~A}$ to form a protective colloidal membrane and thus retards the direct hydration reaction, however, when all the sulphates are consumed, hydration can then accelerate It is also evident that all specimens show appreciable increase in flexural and compressive strength with an increase in curing periods. It was also generally observed that the strength of specimens increases with the corresponding increase in percentage gypsum and a consequent decrease after reaching an optimal value. The faster strength gains and higher ultimate values were observed at optimum gypsum content in the range of $5 \%$ to $6 \%$ for the considered curing periods of 7, 14, 21 and 28 days. The results obtained had confirmed the well-known fact that if the content of gypsum exceeds limiting value, it will lower the strength of cement and it can even lead to poor dimensional stability, which will cause expansion and destruction of cement paste [4].

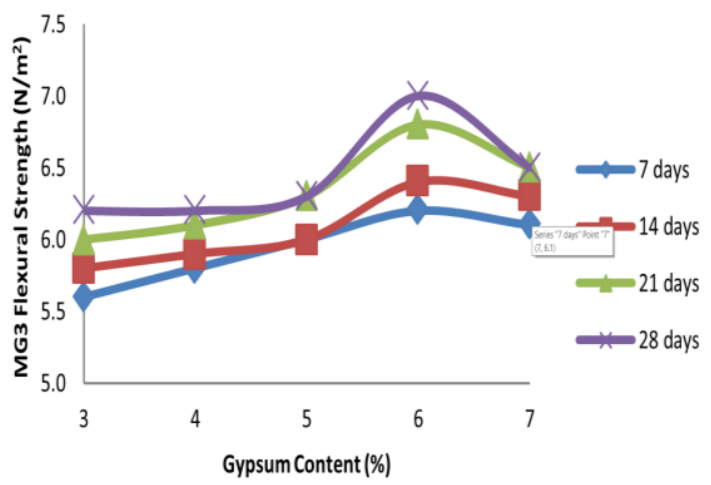

Figure 2: Variation of flexural strength with gypsum content for cement mix group 3 at 7, 14, 21 and 28 days curing period

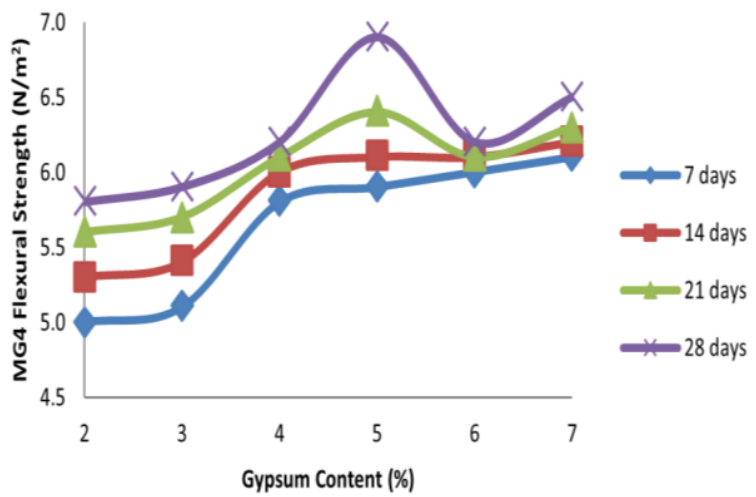

Figure 3: Variation of flexural strength with gypsum content for cement mix group 4 at 7, 14, 21 and 28 days curing period

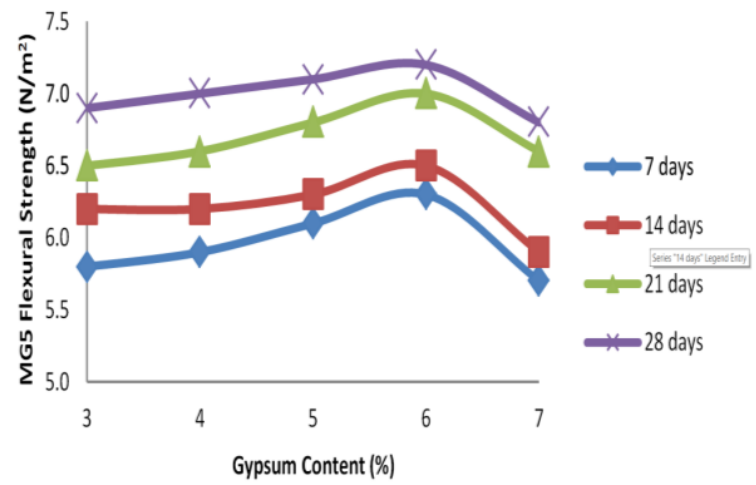

Figure 4: Variation of flexural strength with gypsum content for cement mix group 5 at 7, 14, 21 and 28 days curing period 


\subsection{Microstructure of cement mixes produced}

The microstructure of the cement mortar produced using the four different gypsums/cement clinker blends coded in this study as cement groups microscopic analysis of the cement mortar from the SEM results are presented in this section. The results show 2, 3, 4 and 5 . The results for 7 and 28 days curing periods are considered.

The effect of increase in gypsum content in the microstructures is displayed in Figure 9 to 16. At 7days curing period (Figure 1) and for cement mix group 2, the morphology of the cement mix group 2 looks cloudy, while 28-days sample (Figure 10) shows whitish and spongy appearance indicating more calcium silicate hydrate (C-S-H) enriched regions with dense structure for increased compressive strength. The cement mixes in the group 3 falls within good purity class of gypsum in view of their high percentage of $\mathrm{CaSO}_{4}$ content.

Figures 11 and 12 shows the surface microstructure of the cement mix group 3 , at 7 and 28 days of curing respectively. There is clear variation in the microstructure of the mortar ay 7 and 28 days curing age. The spongy and increased whitish colour of the mortar at 28 days indicate silicate enrichment.

The cement mixes in the group 4 falls within good purity class of gypsum that is better than groups 2 and 3, due to higher quantity of $\mathrm{SO}_{3}$ within the same percentage gypsum.

Figures 13 and 14 shows the surface microstructure of cement mix group 4 after 7 and 28 days of curing respectively. At 7-days (Figure 13) cured samples, there was variation in the structure in relation to the 28 days of curing (Figure 14) owing to the density of the image.

This implies that the 28 days cured samples renders higher amount of hydration products caused by the filling of the cementitious products and bonding among the cement particles. The longer curing time brought about the change in microstructure through continuous hydration of both 7 and 28-days cured samples.

The cement mixes in the group 5 was blended with imported class of gypsum and taken as the control specimen considering its less impurities and high percentage of $\mathrm{CaSO}_{4}$ content. Figures 15 and 16 show the surface microstructure of the cement mix group 5 mortars after 7 and 28 days of curing respectively. At 7-days (Figure 15) cured samples, there is variation in the structure of the images in relation to the 28 days of curing (Figure 16) and presence of more hydration products for the 28-days cured sample that rendered it greater in strength.

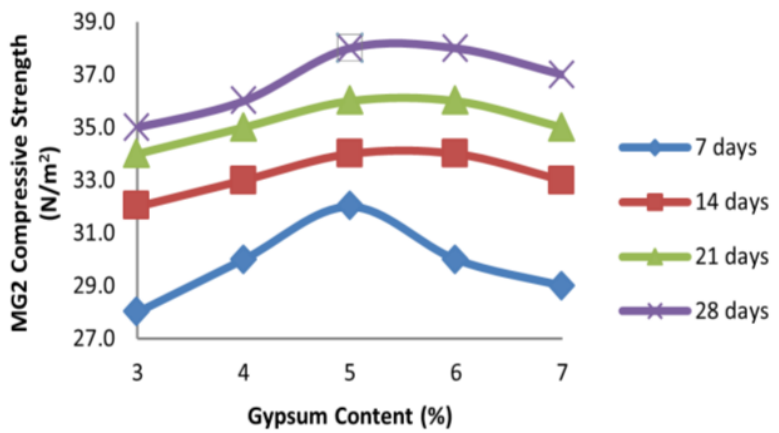

Figure 5: Variation of compressive strength with gypsum content for cement mix group 2 at 7, 14, 21 and 28 days curing period

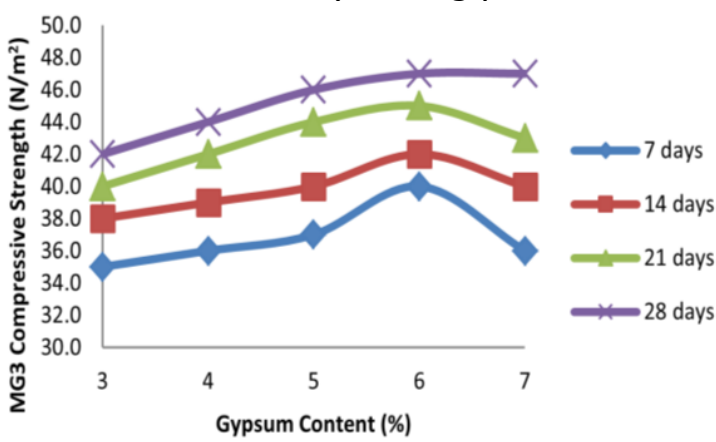

Figure 6: Variation of compressive strength with gypsum content for cement mix group 3 at 7, 14, 21 and 28 days curing period 5

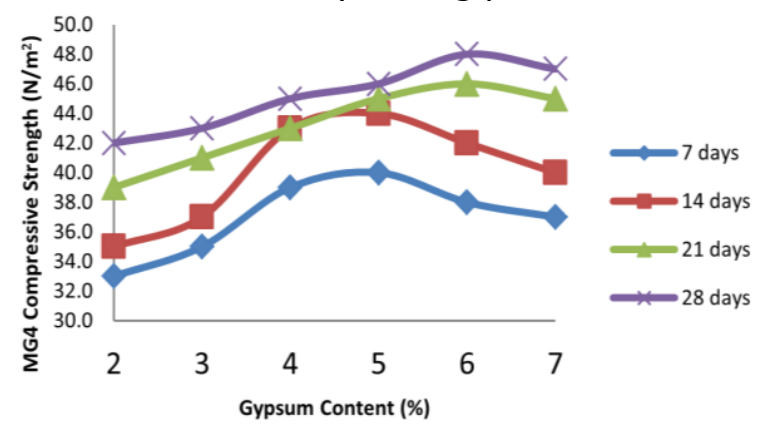

Figure 7: Variation of compressive strength with gypsum content for cement mix group 4 at 7, 14, 21 and 28 days curing period 5

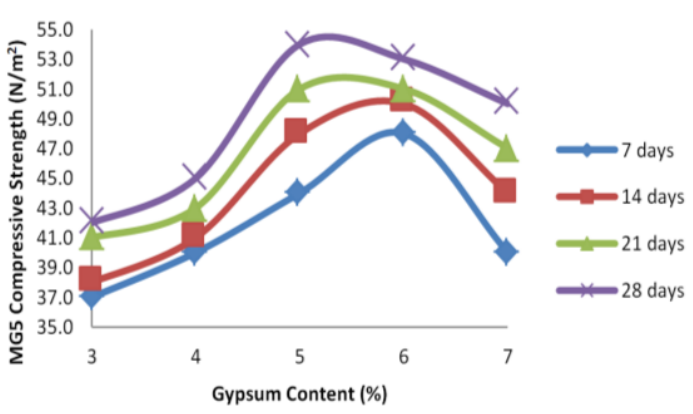

Figure 8: Variation of compressive strength with gypsum content for cement mix group 5 at 7, 14, 21 and 28 days curing period 


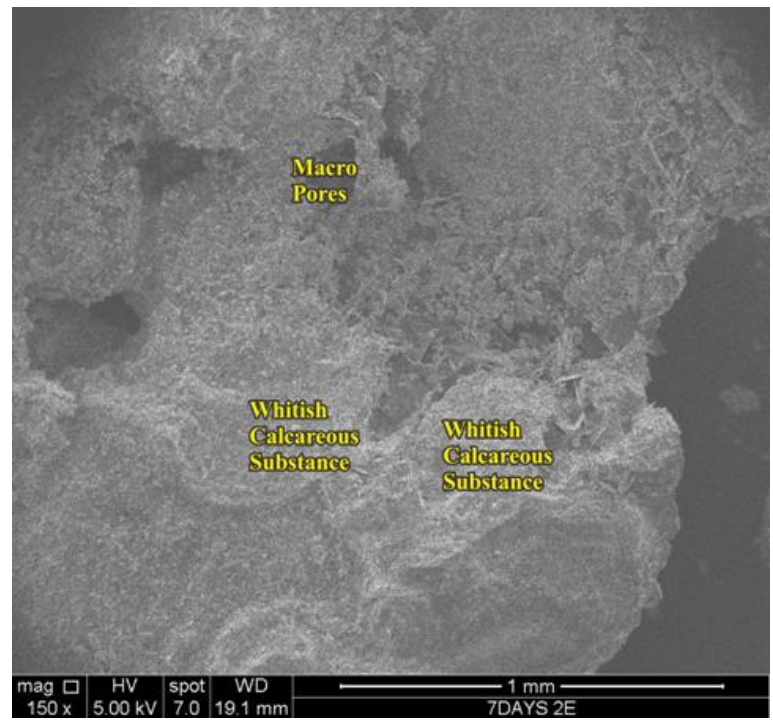

Figure 9: 7-day old cement mortar microstructure image for cement mix group 2

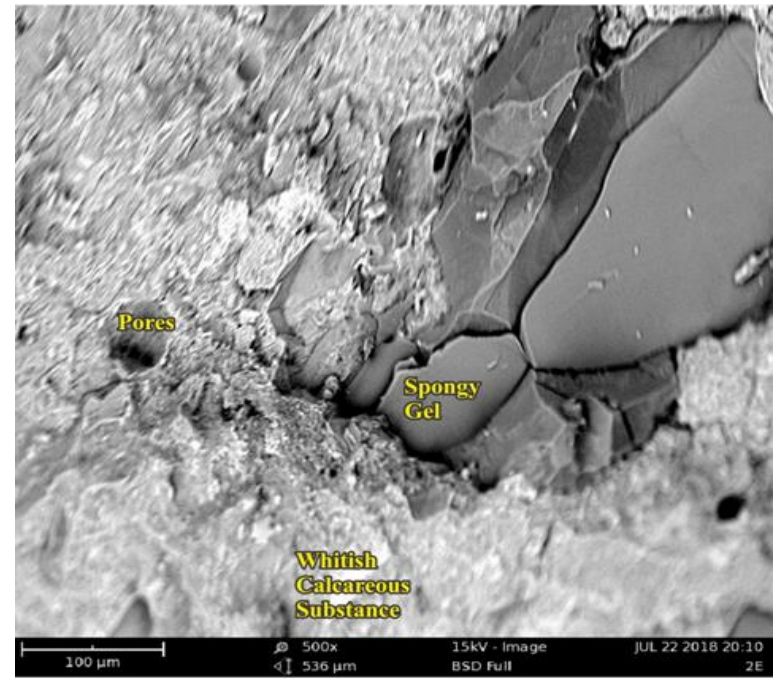

Figure 10: 28-day old cement mortar microstructure image for cement mix group 2

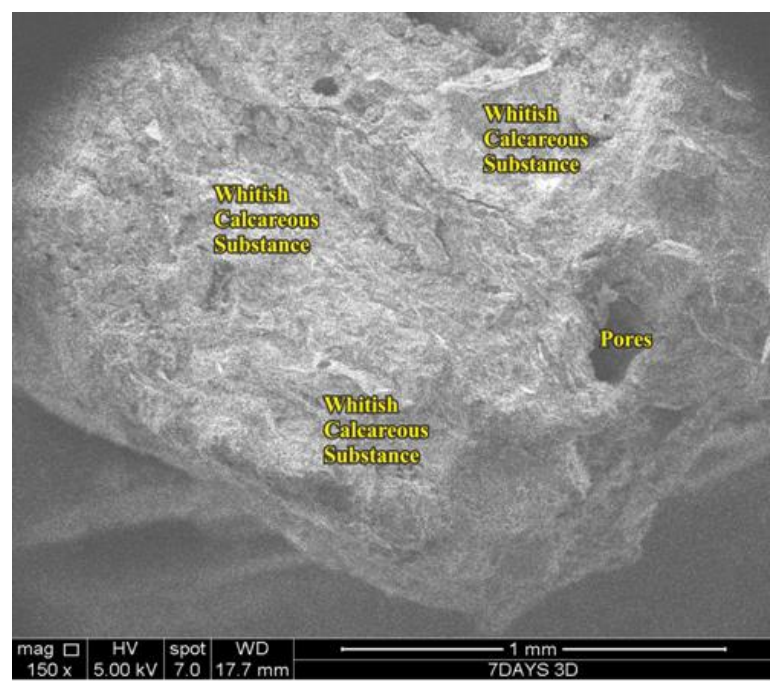

Figure 11: 7-day old cement mortar microstructure image for cement mix group 3

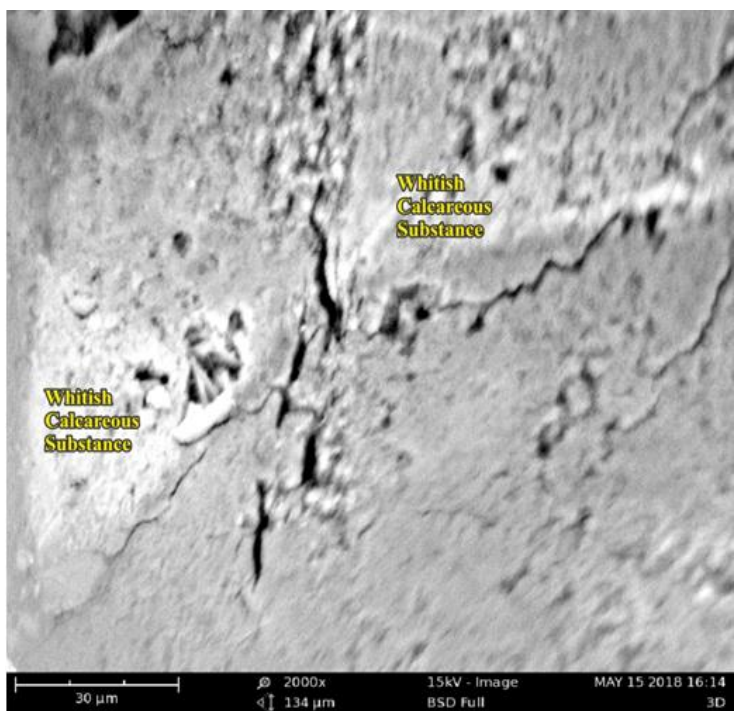

Figure 12: 28-day old cement mortar microstructure image for cement mix group 3

\section{CONCLUSIONS}

The gypsum samples used in this research were sourced from eighteen locations across Nigeria. These were classified into four groups depending on the gypsum purity in this order: $65-70 \%, 70-75 \%$ and greater than $75 \%$ purity. Also gypsum sample sourced outside Nigeria with greater than $75 \%$ purity was also used as control.

Based on the results obtained, the following conclusions are made:

1. The rate of development of mortar strength (flexural and compressive) increases with age and gypsum content regardless of the gypsum quality group.

2. The strength increases on various cement mixes at the various curing period considered were proven by the spongy, gel and whitish colouration, indicating silicates enriched regions from the microstructure of scanning electron microscopy (SEM) analysis.

3. The results show that all but the class one gypsum with less than $65 \%$ purity content are suitable for cement manufacture.

4. The optimum gypsum content was found to be in the range of $5 \%$ to $6 \%$ for both the locally sourced Gypsum and 5\% for the imported Gypsum. An optimum gypsum content of $5.5 \%$ is recommended from this work. Based on this recommendation, the corresponding 28 day strength values are presented in Table 4.0: 
Table 4: 28 Day Flexural and Compressive Strengths Corresponding to 5.5\% Gypsum Content

\begin{tabular}{c|c|c}
\hline $\begin{array}{c}\text { Cement } \\
\text { Mix Group }\end{array}$ & $\begin{array}{c}\text { Flexural } \\
\text { Strength } \\
\left(\mathrm{N} / \mathrm{mm}^{2}\right)\end{array}$ & $\begin{array}{c}\text { Compressive } \\
\text { Strength }\left(\mathrm{N} / \mathrm{mm}^{2}\right)\end{array}$ \\
\hline 2 & 5.5 & 38 \\
3 & 6.7 & 45 \\
4 & 6.5 & 46 \\
5 & 7.1 & 52 \\
\hline
\end{tabular}

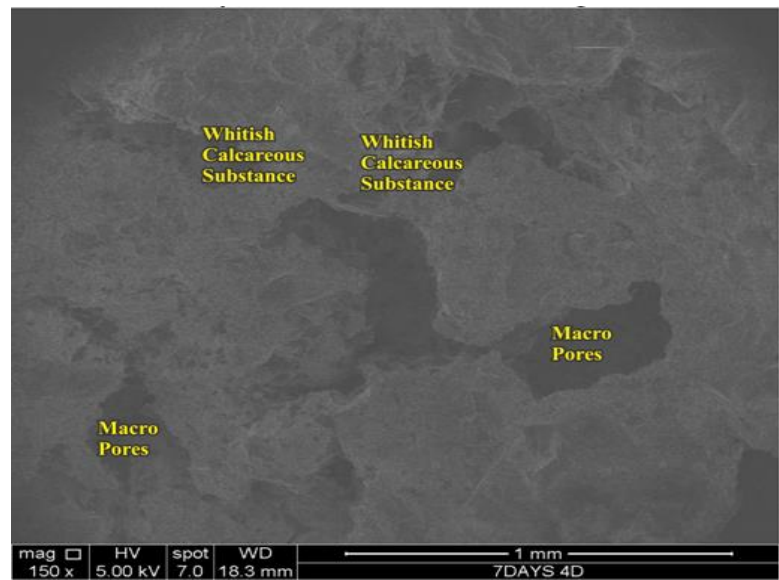

Figure 13: 7-day old cement mortar microstructure image for cement mix group 4

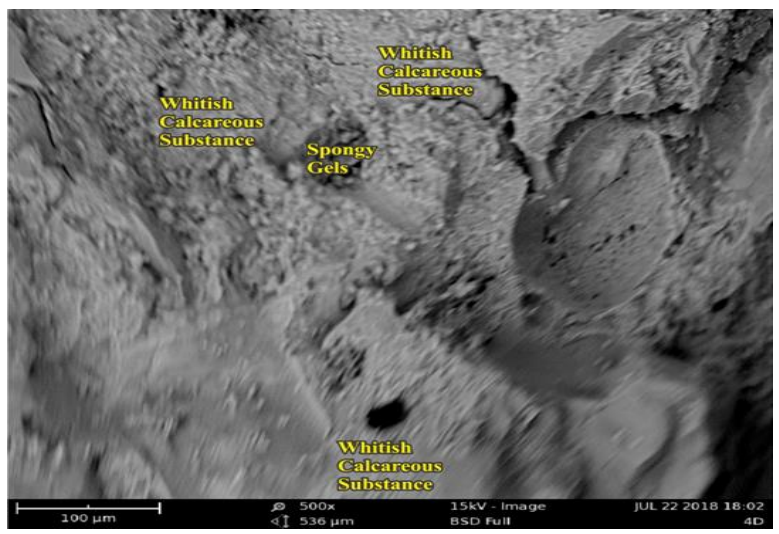

Figure 14: 28-day old cement mortar microstructure image for cement mix group 4

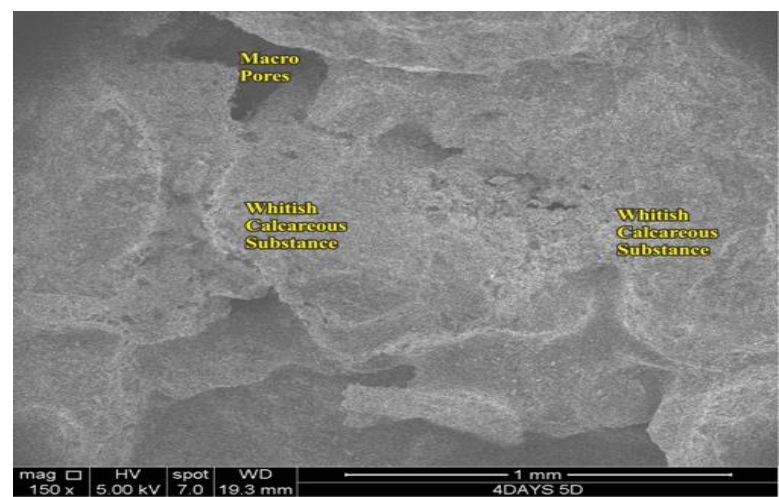

Figure 15: 7-day old cement mortar microstructure image for cement mix group 5

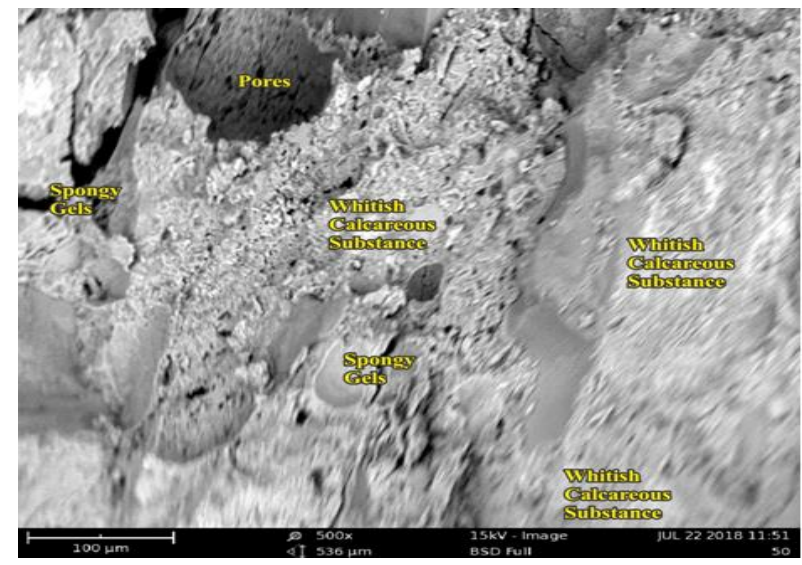

Figure 16: 28-day old cement mortar microstructure image for cement mix group 5

\section{REFERENCES}

[1] Hassaan MY, Effect of Gypsum on the strength development of Portland cement by Mossbauer spectrometry. Hyperfine Interactions, Volume 42, Issue 1-4, pp 1199-1202, 1988.

[2] Taylor, H.F.W The Chemistry of Cements, vol.1, Academic Press, London, pp.1-48, 1990

[3] Laura Dodds Microstructure Characterisation of Ordinary Portland Cement Composites for the Immobilisation of Nuclear Waste. A thesis submitted to the University of Manchester for the degree of Master of Philosophy in the faculty of Engineering and Physical Sciences, 2012

[4] Neville, A. M , Properties of Concrete, Pearson Education Limited, Edinburgh Gate Harlow Essex CM20 2JE England, $5^{\text {th }}$ edition (2011).

[5] Mike L, and Yunhong J, Porosity, Pore Size Distribution, Micro-structure Centre for Innovative Construction Materials, University of Bath, Bath BA2 7AY, UK, 2017.

[6] Bhanumathidas $\mathrm{N}$ and Kalidas $\mathrm{N}$ Dual role of gypsum: Set retarder and strength accelerator, The Indian Concrete Journal, 2004.

[7] Tsamatsoulis D and Nikolakakos N, Optimizing the Sulphates Content of Cement Using Multivariable Modelling and Uncertainty Analysis. Halyps Building Materials S.A, Italcementi Group, 2013.

[8] Kumar $\mathrm{P}$, Mehta $\mathrm{P}$, Monteiro J, CONCRETE Microstructure, Properties and Materials, 2001.

[9] Taher M. A., Amine, A. M. and Dammarany Effect of Partial Substitution of Raw Gypsum with Thermally Treated Phosphogypsum on the Properties of Portland Pozzolanic Cement. Advanced Journal of Chemistry, Section A. Vol. 2, No. Pp. 296-315.

[10] Ameer A. Hilal Microstructure of Concrete, Department of Civil Engineering, Faculty of

Vol. 39, No. 4, October 20201009 
Engineering, University of Anbar, Anbar, Iraq, 2016

[11] Abdelrahman A.A and Mohamad H.A Determination of Optimum quantity of Raw Gypsum addition for Atbara cement Clinker. Faculty of engineering, Khartoum University, 1998.

[12] British Standards Institution Methods of testing cement: Determination of strength. BS EN 1961:2000. London: B British Standards Institution, 2000.

[13] Walker, R., Pavia, S. Impact of Hydration on the Properties of Hemp Lime Concrete. Civil engineering research in Ireland CERAI, Belfast, 2014.
[14] British Standards Institution Cement-Part 1: Composition, specifications and conformity criteria for common cements. London: B British Standards Institution. BS EN 197-1, 2000.

[15] Damisa E.O.A An Overview of Gypsum Occurrences and Processing in Nigeria for Plaster of Paris (POP) and Cement Industries. Raw Materials Research and Development Council (RMRDC), 2016.

[16] Nigerian Industrial Standards NIS 446: METHODS OF TESTING CEMENT- Determination of Strength (ICS 91:100:10). Standards Organization of Nigeria, 2003. 